\title{
SECONDARY HODGKIN LYMPHOMA AND MYELODYSPLASTIC SYNDROME (MDS) AFTER PACLITAXEL-CARBOPLATIN TREATMENT IN A PATIENT WITH SMALL CELL LUNG CANCER
}

\author{
Marija Petrusevska $^{1}$, Irina Panovska Stavridis $^{2}$, Kristina Mladenovska $^{3}$, Gordana Petrushevska $^{4}$ \\ ${ }^{1}$ Institute of preclinical and clinical pharmacology and toxicology, Faculty of Medicine, University "Ss. Cyril and Methodius" \\ Skopje, Republic of Macedonia \\ ${ }^{2}$ University Clinic of hematology, University "Ss. Cyril and Methodius" Skopje, Republic of Macedonia \\ ${ }^{3}$ Department of clinical pharmacy, Faculty of Pharmacy, University "Ss. Cyril and Methodius" Skopje, Republic of Macedonia \\ ${ }^{4}$ Institute of pathology, Faculty of Medicine, University "Ss. Cyril and Methodius" Skopje, Republic of Macedonia
}

Corresponding author: Marija Petrusevska, 50 Divizija 6, 1000, Skopje, Macedonia, e-mail: mapet85@yahoo.com

\begin{abstract}
Herein synchronous occurrence of Hodgkin lymphoma and secondary myelodysplastic syndrome in a 60 year old male patient with small cell lung cancer treated with combined chemotherapy (carboplatin and paclitaxel) and radiotherapy is presented. The objective of this report is to stress the importance of documenting and monitoring adverse drug reactions that arise from chemotherapy.

After four years of treatment with the combined chemotherapy, the patient presented inguinal lymphadenopathy and enlarged lymph nodes and histopathology rapport was suggestive for plasmacytoid variant of Castleman disease. Three years later, biopsy of lymph node was performed and diagnosis of Hodgkin lymphoma - mixed cellularity has been established. Molecular analyses revealed presence of dominant monoclonal population of the immunoglobulin genes in the oligo/monoclonal background. Bone marrow biopsy findings suggested secondary myelodysplasia and revealed signs of hematopoietic cells dismaturation with signs of megaloblastic maturation of the erytropoetic lineage, appearance of ALIP (abnormal localization of immature precursors) in the myeloid lineage and dysplastic megakaryocytes. In addition, an increased level of polyclonal plasmacytes (lambda vs kappa was 60\%:40\%) was found.

Hodgkin lymphoma and MDS occurring after 4 years of carboplatin/paclitaxel therapy might be contributed to the accumulation of alkylator-related DNA damage. This emphasize the need of outlining a monitoring plan regarding development of secondary leukemia and other malignant hematological proliferations should be outlined in the protocols.
\end{abstract}

Keywords: Hodgkin lymphoma, MDS, Castleman disease paclitaxel, carboplatin

\section{INTRODUCTION}

Paclitaxel is a tubulin-binding agent that is widely used for the treatment of small cell lung cancer (SCLC), pancreatic, ovarian, breast and other cancers. The combination of paclitaxel and a platinum compound is an approved regimen for the treatment of advanced SCLC [1-3].
The rapid development of new therapies that improve patients' quality of life and treat various diseases has led to occurrence of more complex adverse drug reactions. This is obvious in cancer therapy where various adverse events are more often neglected by the responsible clinicians because of the primary goal of cancer therapy [4-6]. Hence, documenting and monitoring adverse drug 
reactions that arise from chemotherapy should be done more precisely especially in patients who need therapy longer duration and have cumulative dose.

A recent case report has documented a patient that developed secondary acute myeloid leukemia after several months of treatment with cyclophosphamide, alkylating agent used to treat lymphomas and various cancers [4]. Additionally, Gajendra et al, reported a rare case of Hodgkin lymphoma in a patient with chronic myeloid leukemia treated with imatinib, a tyrosine kinase inhibitor [7].

Herein, we report a patient with SCLC treated with combination of paclitaxel/carboplatin and radiotherapy who developed secondary Hodgkin Lymphoma mixed cellularity subtype accompanied with secondary myelodysplastic syndrome.

\section{CASE DESCRIPTION}

A sixty years old male has been admitted with previously diagnosed SCLC based on native chest X-ray (Figure 1), computer tomography (CT) (Figure 2), and bronchial biopsy rapport (Figure 3 ). His past medical history was insignificant. $\mathrm{He}$ started with first line of chemotherapy and sequential locoregional radiotherapy. The chemotherapy protocol has been consisted from 6 combined cycles of paclitaxel/carboplatin and locoregional radiotherapy with $44 \mathrm{~Gy}$. Soon after treatment, he recovered on clinical radiographic evaluation with complete remission of the disease, without signs of infiltration of the lung with malignant disease.

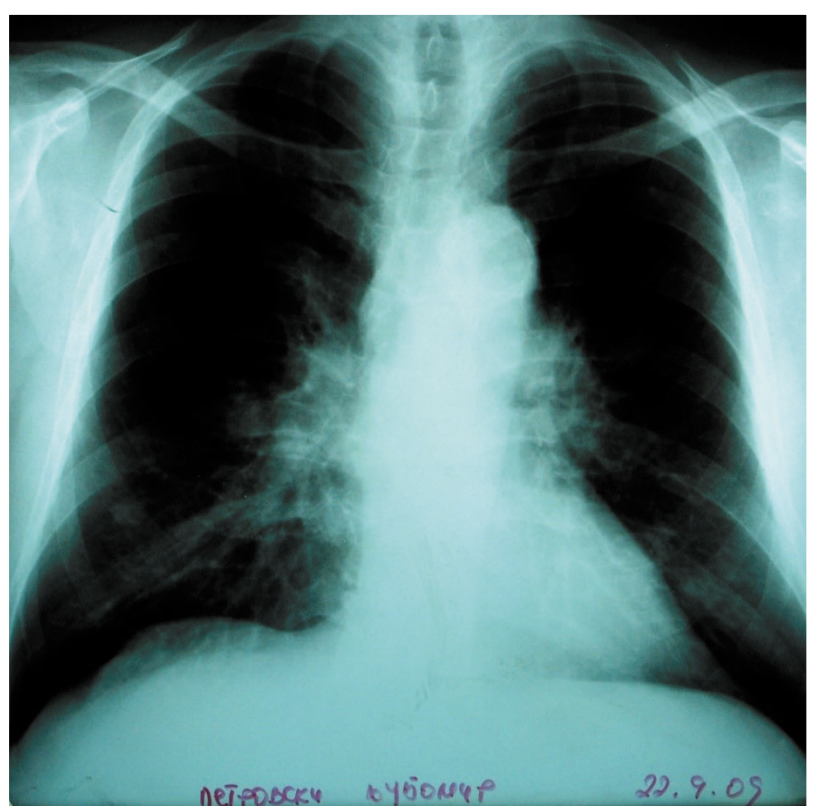

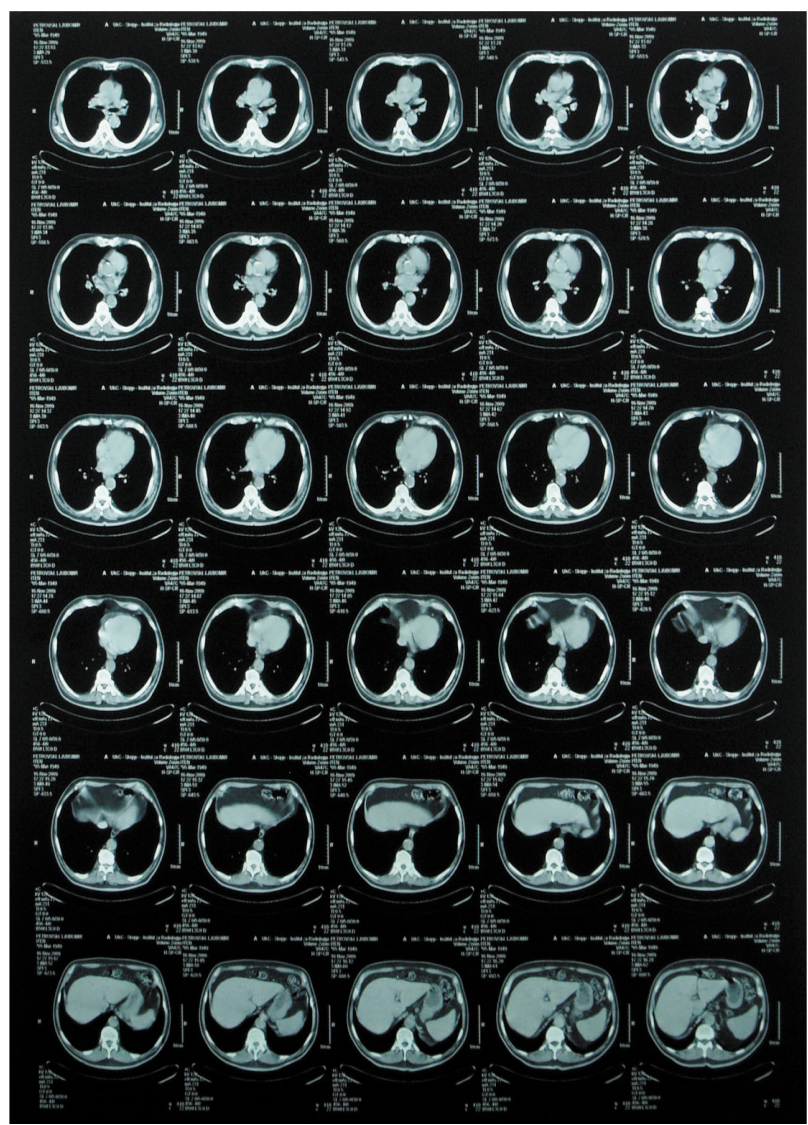

On periodical follow-ups on every six months, patients' laboratory analyses from the peripheral blood, lung, liver and kidney function tests were within normal range. After four years, the patient presented with inguinal lymphadenopathy and enlarged lymph nodes in the retroperitoneal region

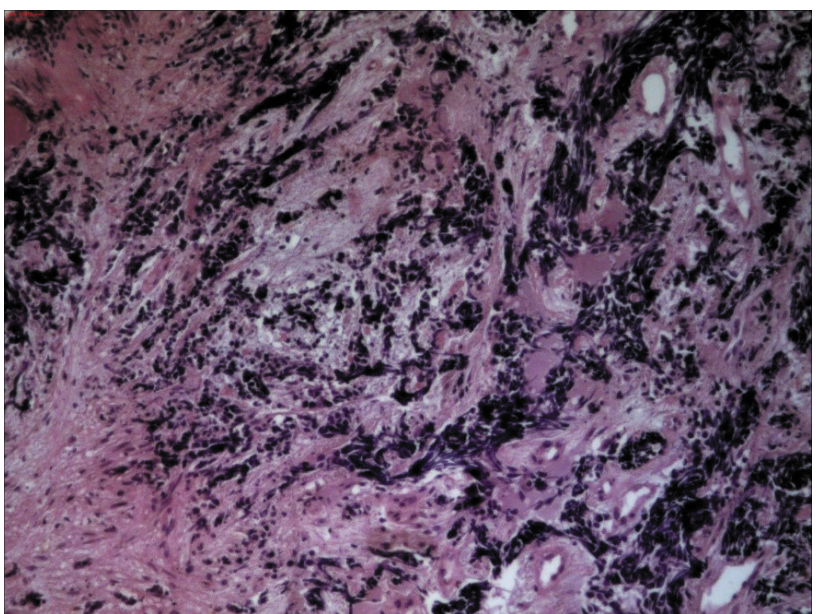

on CT. CT also revealed lung fibrosis without enlarged mediastinal lymph nodes. Lymphadenectomy from the inguinal region has been done and the results from the histopathology report were suggestive for plasmacytoid variant of Castleman disease (Figure 4). Axillary lymphadenectomy followed descriptive histological finding for re- 
active lesion. Patient was treated with antibiotics and there was improvement of the clinical picture with regression of the enlarged lymph nodes.

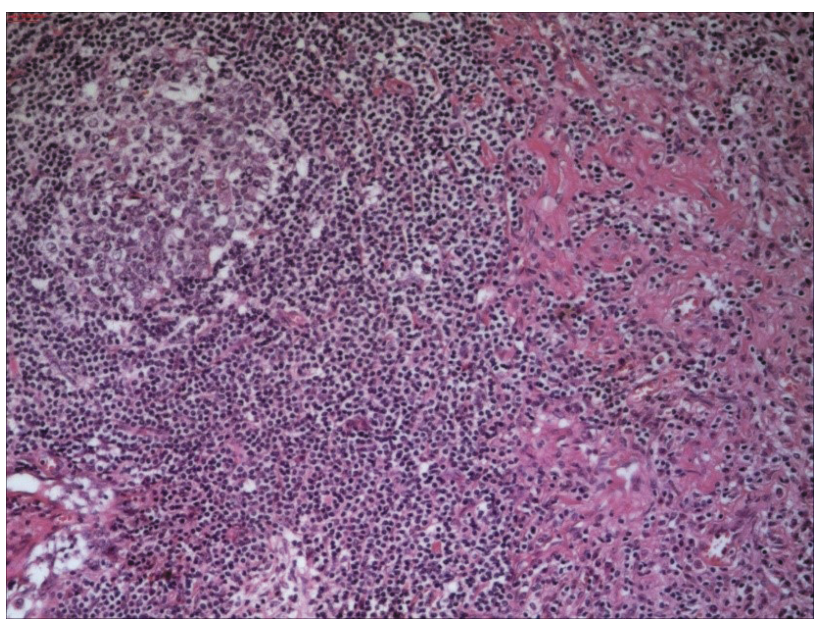

Three years later, the patient was admitted at the University Clinic of Hematology, with complaints of fatigue, prostration and increased sweating.

Physical and ultrasound examination revealed cervical, supraclavicular, axillary and inguinal lymphadenopathy with no hepatosplenomegaly. Mediastinal lymphadenopathy was found on CT scan. Abdominal CT scan examination revealed regular liver architecture, slightly enlarged spleen with hypodense region measuring $17 \mathrm{~mm}$, combined with retroperitoneal and mesenterial lymphadenopathy.

Patients' pertinent hematology and biochemistry laboratory investigation are shown in Table 1. Peripheral blood smear was normal. Lymph node biopsy from the axillary region has been done. A diagnosis of Hodgkin`s lymphomamixed cellularity has been established (Figure 5). Molecular analyses revealed presence of dominant monoclonal population of the immunoglobulin

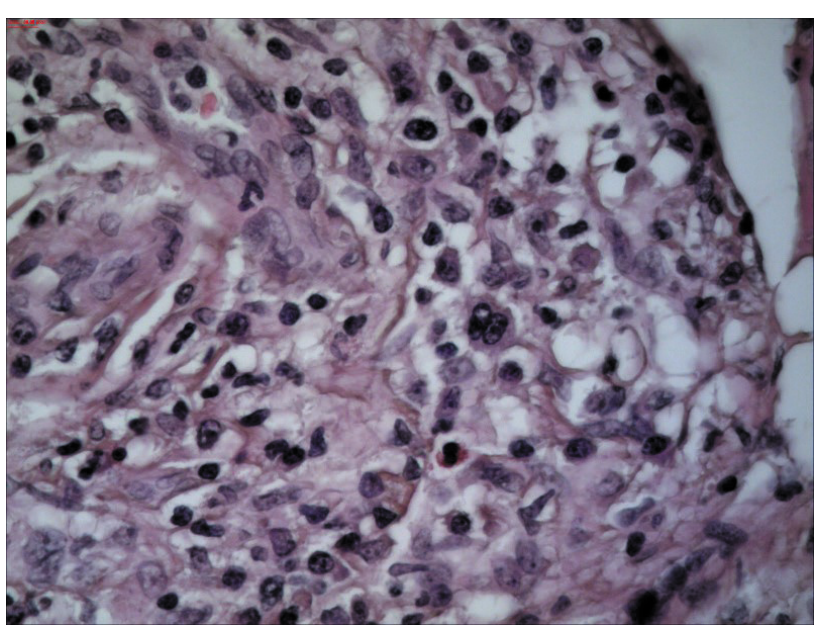

Table 1. Hematology and biochemistry laboratory results

\begin{tabular}{|c|c|c|c|}
\hline 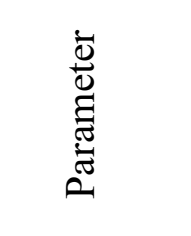 & 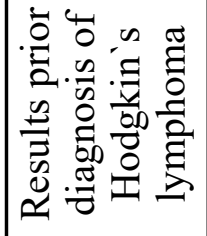 & 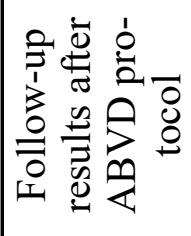 & 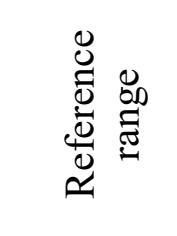 \\
\hline WBC & $\begin{array}{l}8.17 \mathrm{x} \\
103 / \mu \mathrm{L}\end{array}$ & \begin{tabular}{|l|}
$2.32 \mathrm{x}$ \\
$103 / \mu \mathrm{L}$
\end{tabular} & $\begin{array}{l}4.00- \\
10.50 \mathrm{x} \\
103 / \mu \mathrm{L}\end{array}$ \\
\hline $\begin{array}{l}\text { Neutro- } \\
\text { phil }\end{array}$ & \begin{tabular}{|l|}
$6.19 x$ \\
$103 / \mu \mathrm{L}$
\end{tabular} & $\begin{array}{l}1.41 \mathrm{x} \\
103 / \mu \mathrm{L}\end{array}$ & $\begin{array}{l}1.40-6.50 \\
\times 103 / \mathrm{uL}\end{array}$ \\
\hline $\begin{array}{l}\text { Lympho- } \\
\text { cyte }\end{array}$ & $\begin{array}{r}1.19 \mathrm{x} \\
103 / \mu \mathrm{L} \\
\end{array}$ & \begin{tabular}{|l|}
$0.57 x$ \\
$103 / \mu \mathrm{L}$ \\
\end{tabular} & $\begin{array}{l}1.20-3.40 \\
\times 103 / \mu \mathrm{L} \\
\end{array}$ \\
\hline Monocyte & \begin{tabular}{|l|}
$0.40 \mathrm{x}$ \\
$103 / \mu \mathrm{L}$ \\
\end{tabular} & \begin{tabular}{|l|l|}
$0.24 \mathrm{x}$ \\
$103 / \mu \mathrm{L}$ \\
\end{tabular} & $\begin{array}{l}0.00-0.60 \\
\times 103 / \mu \mathrm{L} \\
\end{array}$ \\
\hline $\begin{array}{l}\text { Eosino- } \\
\text { phil }\end{array}$ & \begin{tabular}{|l}
$0.38 \mathrm{x}$ \\
$103 / \mu \mathrm{L}$ \\
\end{tabular} & $\begin{array}{l}0.10 \mathrm{x} \\
103 / \mu \mathrm{L} \\
\end{array}$ & $\begin{array}{l}0.00-0.70 \\
\times 103 / \mu \mathrm{L} \\
\end{array}$ \\
\hline Basophil & \begin{tabular}{|l}
$0.01 \times$ \\
$103 / \mu \mathrm{L}$ \\
\end{tabular} & \begin{tabular}{|l|l|}
$0.00 \mathrm{x}$ \\
$103 / \mu \mathrm{L}$ \\
\end{tabular} & $\begin{array}{l}0.00-0.20 \\
\times 103 / \mu \mathrm{L} \\
\end{array}$ \\
\hline $\mathrm{RBC}$ & $\begin{array}{l}3.02 \times \\
106 / \mu \mathrm{L}\end{array}$ & $\begin{array}{l}2.57 \mathrm{x} \\
106 / \mu \mathrm{L}\end{array}$ & $\begin{array}{l}4.00-6.00 \\
\times 106 / \mu \mathrm{L}\end{array}$ \\
\hline HGB & $8.3 \mathrm{~g} / \mathrm{dL}$ & $7.2 \mathrm{~g} / \mathrm{dL}$ & $\begin{array}{l}11.0- \\
18.0 \mathrm{~g} / \mathrm{dL}\end{array}$ \\
\hline HCT & $26.3 \%$ & $23.3 \%$ & $\begin{array}{l}35.0- \\
60.0 \%\end{array}$ \\
\hline PLT & $\begin{array}{l}78 \times 103 / \\
\mu \mathrm{L}\end{array}$ & $\begin{array}{l}99 \times 103 / \\
\mu \mathrm{L}\end{array}$ & $\begin{array}{l}150-450 / \\
\mu \mathrm{L}\end{array}$ \\
\hline Glucose & $\begin{array}{l}7.13 \\
\mathrm{mmol} / \mathrm{L}\end{array}$ & - & $\begin{array}{l}3.89-6.40 \\
\mathrm{mmol} / \mathrm{L}\end{array}$ \\
\hline Urea & \begin{tabular}{|l|}
6.2 \\
$\mathrm{mmol} / \mathrm{L}$ \\
\end{tabular} & - & $3.0-9.2$ \\
\hline $\begin{array}{l}\text { Creati- } \\
\text { nine }\end{array}$ & $\begin{array}{l}89.5 \\
\mu \mathrm{mol} / \mathrm{L}\end{array}$ & - & $\begin{array}{l}63.6- \\
110.5 \\
\mu \mathrm{mol} / \mathrm{L} \\
\end{array}$ \\
\hline AST & $11 \mathrm{U} / \mathrm{L}$ & - & $5-34 \mathrm{U} / \mathrm{L}$ \\
\hline ALT & $7 \mathrm{U} / \mathrm{L}$ & - & $0-55 \mathrm{U} / \mathrm{L}$ \\
\hline $\begin{array}{l}\text { Alkaline } \\
\text { phospha- } \\
\text { tase }\end{array}$ & $67 \mathrm{U} / \mathrm{L}$ & - & $\begin{array}{l}40-150 \\
\mathrm{U} / \mathrm{L}\end{array}$ \\
\hline Bilirubin & $\begin{array}{l}31.7 \\
\mu \mathrm{mol} / \mathrm{L}\end{array}$ & - & $\begin{array}{l}3.4- \\
20.5 \\
\mu \mathrm{mol} / \mathrm{L}\end{array}$ \\
\hline Albumin & $31 \mathrm{~g} / \mathrm{L}$ & - & $35-52 \mathrm{~g} / \mathrm{L}$ \\
\hline $\mathrm{Fe}$ & $\begin{array}{l}6.2 \\
\mu \mathrm{mol} / \mathrm{L}\end{array}$ & - & $\begin{array}{l}11.6 \\
-31.3 \\
\mu \mathrm{mol} / \mathrm{L}\end{array}$ \\
\hline
\end{tabular}


genes in the oligo/monoclonal background. After echocardiographic evaluation of the cardiac function and spirometry for the respiratory capacity that revealed signs of borderline pulmonary arterial hypertension, the patient was further treated for secondary malignant disease Hodgkin lymphoma by ABVD protocol. The hematology results and differential leukocyte count, after applied two cycles of treatment with ABVD D1C1 and ABL D1D2 are shown in Table 1.

Bone marrow biopsy has been done with findings of secondary myelodysplasia (Figure 6). Histological analysis of the bone marrow biopsy revealed signs of hematopoietic cells dismaturation with signs of megaloblastic maturation of the erytropoietic lineage, appearance of ALIP in the myeloid lineage and dysplastic megakaryocytes. In addition, it was found an increased level of polyclonal plasmacytes (lambda vs kappa was 60\%:40\%).

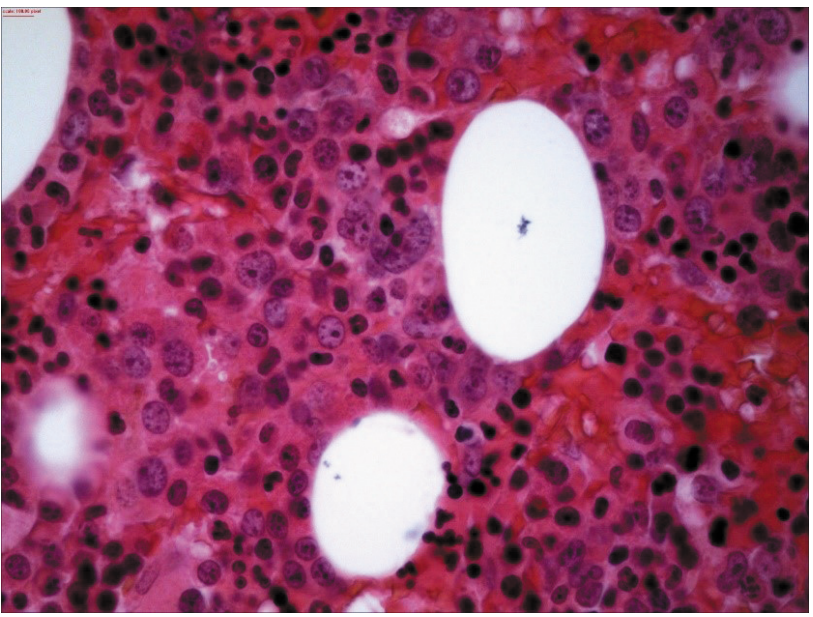

\section{DISCUSSION}

Herein, we report the synchronous occurrence of Hodgkin lymphoma and secondary MDS in a patient with SCLC treated with combined chemotherapy (carboplatin and paclitaxel) and radiotherapy currently on chemotherapy. It is possible that carboplatin and/or paclitaxel contributed likely to the accumulation of alkylator-related DNA damage, due to a predisposition to the myelotoxic effects of chemotherapy [2-6].

Secondary myelodysplastic syndrome or secondary leukemia to chemotherapy usually develops four to seven years after the initial exposure and is often seen in young patients [8-10]. The most common abnormalities are related to chromosomes 5 and 7. Alkylating agents have been considered the most common drugs associated with $\operatorname{MDS}[6,11,12]$.

Although the potential contribution of paclitaxel and carboplatin to the induction of Hodgkin lymphoma and MDS is controversial, only few cases of the secondary diseases, particularly MDS and leukemia are reported in the literature where only carboplatin and paclitaxel were used as primary chemotherapy, but no radiotherapy $[2$, $12,13]$. To the best of our knowledge, there are not available data for the synchronous appearance of myelodysplasia and Hodgkin lymphoma. The individual impact of each treatment is uncertain in the presented case, even though the exposure to carboplatin and/or paclitaxel in combination with radiotherapy might have played a role in the development of therapy-related MDS. That might be the first hit in the process of development of the Hodgkin disease due to the escape of the immune surveillance in the condition of dysfunctional immune cells. This hypothesis is supported also by the appearance of the Castelman disease previously in the patient. There have been described therapy-related MDS/AML following cytotoxic chemotherapy of malignant tumors with classic alkylating agents, including nitrosoureas or procarbazin, radiation therapy alone, or combined chemotherapy and radiotherapy $[14,15]$. The risk is higher in elderly patients, and there are no known factors other than age and duration of therapy to predict which patients might be at higher risk of the secondary diseases.

In a review including 28 cases of the secondary diseases, the median latency between the start of therapy and the diagnosis of therapy-related MDS/AML was 2.5 years $[15,16]$. Our patient with SCLC developed Castelman disease three years after combined chemotherapy and radiotherapy. However, he was in good condition in the next three years when he manifested symptoms of Hodgkin disease and immediately symptoms of pancytopenia during the first two cycles of the ABVD-based chemotherapy. The development of MDS is related to the specific DNA-damaging agents, dose, therapy duration, and patient age [6, $11,17]$. The mechanism of the secondary disease occurrence related to carboplatin and paclitaxel remains to be determined. It is unlikely that this is a direct effect of carboplatin and paclitaxel only, since our patient has received also radiation thera- 
py. It has been reported that the risk of developing secondary MDS and AML depends on the total exposure of chemotherapy and radiotherapy [14, $18,20]$. Hence, patients that are under long-term treatment must be followed-up carefully. This risk of developing secondary disease also depends of the age of the patient which must be considered by clinicians when developing treatment plan for cancer patients.

\section{CONCLUSION}

A monitoring plan regarding development of secondary leukemia and other malignant hematological proliferations should be outlined in the oncology protocols. Within the context of multi-agent chemotherapy regimens, in our case paclitaxel and carboplatin together with radiotherapy, we underline the importance of following the symptoms during and after the treatment, especially in patients that undergo longer chemotherapy and are exposed to high cumulative dose. To the best of our knowledge Hodgkin lymphoma in a case of SCLC has not been yet reported. Additionally, further studies are also needed to explain and understood the pathogenic relationship between the two entities and to assess the risk of Hodgkin lymphoma in SCLC patients treated with combination of chemotherapy (paclitaxel and carboplatin) and radiotherapy.

\section{REFERENCES}

1. Karim SM, Zekri J. Chemotherapy for small cell lung cancer: a comprehensive review. Oncol Rev 2012;6:16-36.

2. Yeasmin $\mathrm{S}$, Nakayama K, Ishibashi M, Oride A, Katagiri A, Purwana IN, Iida K, Nakayama N, Ishikura H, Miyazaki K. Therapy-related myelodysplasia and acute myeloid leukemia following paclitaxel- and carboplatin-based chemotherapy in an ovarian cancer patient: a case report and literature review. Int J Gynecol Cancer 2008;18(6):1371-6.

3. Wolf S, Barton D, Kottschade L, Grothey A, Loprinzi C. Chemotherapy-induced peripheral neuropathy: Prevention and treatment strategies. Eur J Cancer 2008;44:1507-15.

4. Koklu H, Tufan A, Erkul Y, Akyurek N, Civelek R. Secondary acute myeloid leukemia arising ear- ly after cyclophosphamide treatment. Int J Clin Pharm 2015;37(2):289-91.

5. See HT, Thomas DA, Bueso-Ramos C, Kavanagh J. Secondary leukemia after treatment with paclitaxel and carboplatin in a patient with recurrent ovarian cancer. Int J Gynecol Cancer 2006;16:23640.

6. Bhatia S. Therapy-related myelodysplasia and acute myeloid leukemia. Semin Oncol. 2013; 40(6): $10-24$

7. Gajendra A, Sharma A, Sharma R, Gupta SK, Sood N, Sachdev R. Hodkin Lymphoma in a case of chronic myeloid leukemia treated with tyrosine kinase inhibitors. Turk Patoloji Derg 2017; (ahead of print).

8. Lucy A. Godley, Richard A. Larson. Therapy-related Myeloid Leukemia. Semin Oncol 2008;35(4):418-29.

9. Armitage JO, Carbone PP, Connors JM, Levine A, Bennett JM, Kroll S. Treatment-related myelodysplasia and acute leukemia in non-Hodgkin's lymphoma patients. J Clin Oncol 2003;21(5):897-906.

10. Pinheiro RF, Chauffaille ML. Myelodysplastic syndrome secondary to chemotherapy or radiotherapy - treatment-related MDS. Rev Bras Hematol Hemoter 2006;28(3):201-3.

11. Pedersen-Bjergaard J, Andersen MK, Andersen MT, Christiansen DH. Genetics of therapy-related myelodysplasia and acute myeloid leukemia. Leukemia 2008;22: 240-8

12. Seymour JF, Juneja SK, Campbell LJ, Ellims PH, Estey EH, Prince HM. Secondary acute myeloid leukemia with inv(16): report of two cases following paclitaxel-containing chemotherapy and review of the role of intensified ara-C therapy. Leukemia 1999;13(11):1735-40.

13. Tasaka T, Matsuhashi Y, Uehara E, Tamura T, Kakazu N, Abe T, Nagai M. Secondary acute monocytic leukemia with a translocation $\mathrm{t}(8 ; 16)$ (p11;p13): case report and review of the literature. Leuk Lymphoma 2004;45(3):621-5.

14. Ishikawa M, Nakayama K, Rahman MT, Rahman M, Katagiri H, Katagiri A, Ishibashi T, Iida K, Nakayama N, Miyazaki K. Therapy-related myelodysplastic syndrome and acute myeloid leukemia following chemotherapy (paclitaxel and carboplatin) and radiation therapy in ovarian cancer: a case report. Eur J Gynaec Oncol 2014;35(4):443-8.

15. Takagi $\mathrm{H}$, Ichigo $\mathrm{S}$, Matsunami $\mathrm{K}$, Takagi $\mathrm{H}$, Ikeda T, Murase T, Imai A. Occurrence of myelodysplastic syndrome during paclitaxel and carboplatin-based chemotherapy for recurrent ovarian cancer: Case report. Open J Obst Gynec 3:232-4.

16. Noronha V, Berliner N, Ballen KK, Lacy J, Kracher J, Baehring J, Henson JW. Treatment-related my- 
elodysplasia/AML in a patient with a history of breast cancer and an oligodendroglioma treated with temozolomide: Case study and review of the literature. Neuro-oncol 2006;8(3):280-3.

17. Kumar CC. Genetic Abnormalities and Challenges in the Treatment of Acute Myeloid Leukemia. Genes Cancer 2011;2(2):95-107.

18. Josting A, Wiedenmann S, Franklin J, May M, Sieber M, Wolf J, Engert A, Diehl V. Secondary myeloid leukemia and myelodysplastic syndromes in patients treated for Hodgkin's disease: a report from the German Hodgkin's lymphoma study group. J Clin Oncol 2003;21(18):3440-6.

19. Ng AK, Patricia Bernardo MV, Weller E, Backstrand K, Silver B, Marcus KC, Tarbell NJ, Stevenson MA, Friedberg JW, Mauch PM. Second malignancy after Hodgkin disease treated with radiation therapy with or without chemotherapy: long-term risks and risk factors. Blood 2002;100:1989-96.

20. Groen HJ, Fokkema E, Biesma B, Kwa B, van Putten JW, Postmus PE, Smit EF. Paclitaxel and carboplatin in the treatment of small-cell lung cancer patients resistant to cyclophosphamide, doxorubicin, and etoposide: a non-cross-resistant schedule. J Clin Oncol 1999;17(3):927-32.

Abbreviations

SCLC - small cell lung cancer

ABVD - adriamycin, bleomycin, vinblastine, dacarbazine

$\mathrm{RBC}$ - red blood cell

WBC - white blood cell

HGB - hemoglobin

HCT - hematocrit

PLT - platelets

AST - aspartate aminotransferase

ALT - alanine transaminase

MDS - myelodysplastic syndrome

ALIP - abnormal localization of immature precursors 
Резиме

\title{
РАЗВОЈ НА СЕКУНДАРЕН ХОЧКИНОВ ЛИМФОМ И МИЕЛОДИСПЛАСТИЧЕН СИНДРОМ (МДС) ПО ТРЕТМАН СО ПАКЛИТАКСЕЛ-КАРБОПЛАТИН КАЈ ПАЦИЕНТ СО СИТНОКЛЕТОЧЕН БЕЛОДРОБЕН КАРЦИНОМ
}

\author{
Марија Петрушевска ${ }^{1}$, Ирина Пановска-Ставридис ${ }^{2}$, \\ Кристина Младеновска ${ }^{3}$, Гордана Петрушевска ${ }^{4}$
}

\footnotetext{
${ }^{1}$ Институт за претклиничка и клиничка фармакологија со токсикологија, Универзитет „Св. Кирил и Методиј“, Медицински факултет, 50 дивизија бб, 1000 Скопје, Република Македонија

${ }^{2}$ Универзитетска Клиника за хематологија, Универзитет „Св. Кирил и Методиј“, Медицински факултет, бул. Мајка Тереза бб, 1000, Скопје, Република Македонија

${ }^{3}$ Институт за клиничка фармација, Универзитет, „Св. Кирил и Методиј“, Фармацевтски факултет, 50 дивизија бб, 1000, Скопје, Република Македонија

${ }^{4}$ Институт за патологија, Универзитет, „Св. Кирил и Методиј“, Медицински факултет, 50 дивизија бб, 1000, Скопје, Република Македонија
}

Презентираме синхронизирана појава на Хочкинов лимфом и секундарен миелодиспластичен синдром кај 60-годишен пациент со ситноклеточен рак на белите дробови, третиран со комбинација на хемотерапија (карбоплатин и паклитаксел) и радиотерапија. Целта на овој случај е да се нагласи важноста за документација и следење на несаканите реакции што се појавуваат од хемотерапијата.

По четири години од третманот со комбинирана хемотерапија, пациентот презентирал ингвинална лимфаденопатија и зголемени лимфни жлезди со патохистолошки наод сугестивен за плазмацитоидна варијација на Кастелмановата болест. Три години подоцна, со изведба на биопсија на лимфен јазол, воспоставена е дијагноза на Хочкининов лимфом. Со користење на молекуларни анализи потврдено е присуството на доминантна моноклонална популација на имуноглобулинските гени во олиго/моноклонална заднина. Биопсијата на коскената срцевина сугерираше присуство на секундарна миелодисплазија и потврди знаци на незрелост на хематопоетичните клетки со знаци на мегалобластна матурација на еритопоетичната линија, појава на ALIP (абнормална локализација на незрели прекурсори) во миелоидната линија и присуство на диспластични мегакариоцити. Исто така, најдено беше и покачено ниво на поликлонални плазмацити (lambda vs kappa $60 \%: 40 \%$ ).

Сметаме дека карбоплатинот и/или паклитакселот придонесуваат за акумулација на алкилаторските оштетувања на ДНК поради предиспозицијата на миелотоксичниот ефект од хемотерапијата. Сметаме дека е неопходно да ја потенцираме потребата за поставување план за мониторинг во однос на потенцијалниот развој на секундарна леукемија и друга малигна хематолошка пролиферација во онколошките протоколи.

Клучни зборови: Хочкинов лимфом, миелодиспластичен синдром, паклитаксел, карбоплатин 